\title{
Combined Use of Interferon Alpha-2b Drugs with Tetravalent Vaccine against Reinfection in HPV Female Patients
}

\author{
Nina V. Zarochentseva ${ }^{1 *}$, Julia M. Belaiya ${ }^{1}$, Valentina V. Malinovskaya ${ }^{2}$
}

\author{
${ }^{1}$ Moscow Regional Research Institute of Obstetrics and Gynecology, Moscow, RUSSIA \\ ${ }^{2}$ National Research Center for Epidemiology and Microbiology named after Honorary Academician N.F. Gamalei, Moscow, RUSSIA \\ *Corresponding Author: ninazar11@mail.ru
}

Citation: Zarochentseva NV, Belaiya JM, Malinovskaya VV. Combined Use of Interferon Alpha-2b Drugs with Tetravalent Vaccine against Reinfection in HPV Female Patients. Electron J Gen Med. 2020;17(6):em257. https://doi.org/10.29333/ejgm/8369

ARTICLE INFO

Received: 21 Feb. 2020

Accepted: 26 May 2020

\begin{abstract}
Introduction: The most widespread viral infection of the urogenital tract, papillomavirus infection is the cause of precancerous lesions and HPV-related cancers of various sites. Although in young women, the majority of lesions caused by HPV cause no symptoms and improve spontaneously, the permanent presence of HPV in the organism can lead to an oncological disease developing. With regard to this, the possibility of human papillomavirus reinfection throughout life and the presence of multiple HPV types in one female patient, which inevitably increases the risk of HPV-associated precancerous diseases developing in young women, too, are especially relevant.
\end{abstract}

Objective of the research: optimization of the management tactics of HPV-positive young women by using interferon alpha and tetravalent vaccine.

Materials and methods: The research involved female patients aged 16 to 25 infected with human papillomavirus. The groups under comparison underwent observation, vaccination with tetravalent vaccine, and the use of interferon alpha- $2 b$ combined with vaccination.

Results and conclusion: The research has shown that the management tactics of HPV-positive young women including the use of interferon alpha and tetravalent vaccine helps increase the extent of elimination of the virus and prevents relapses of the viral infection and HPV-associated diseases as compared to female patients from the comparison groups.

Keywords: human papillomavirus, HPV-associated diseases, young women, interferon alpha, tetravalent vaccine

\section{INTRODUCTION}

According to the data of the World Health Organization, papillomavirus infection (PVI) is found in all regions of the world, with around 6 million cases of getting infected with HPV registered annually. However, it does not seem possible to estimate its true incidence rate, as the majority of infection cases feature no symptoms and end in self-recovery. The source of the infectious agent is a person having it. The prevailing transmission mechanism of HPV is the contact one, the main route of transmitting the agent is the sexual one (genital-to-genital, manual-to-genital, oral-to-genital), although transmission by direct touching is possible, too (skin contact). In women, the HPV infection peak falls to the age of 16-25 and it goes down in the later age. By contrast, in men, the PVI peak is at the older age than in women, remaining constant or showing minor decrease as they mature. The statistical data on the PVI incidence rate in Russia are presented by studies from individual regions, because there is no system of mass screening for HPV and precancerous cervical lesions typing set up in the country in general.
According to the data of studies conducted in Russia, signs of $\mathrm{PVI}$ are detected in $15-34,4 \%$ of women of the general population (1). In some regions of Russia, the incidence of genital condylomatosis reaches $120-150$ per 100000 people of the population (2). HPV-infection is most widespread among adolescents aged 15-19. The peak of the frequency of PVI incidence in women is observed at the age of 18 to 24 years old; meanwhile, the PVI detection frequency in women under 24 is 2 times higher than in those older than $35(2,3)$. Featuring the high specificity, different types of HPV cause various lesions of the skin and mucous membranes. Clinical manifestations of the genital HPV-infection range from subclinical signs to the cervical cancer. The result of transforming action of the virus is high-grade dysplasia, progressing development of which leads to cancer (4). The proven fact of progression of papillomavirus infection into malignant neoplasm has allowed estimating the scale of the problem of HPV-associated diseases and various site cancers.

In the majority of the infected ones, the virus is eliminated with the course of time, ranging from 10 to $90 \%$ according to the data of various authors (5). Results of prospective studies of HPV persistence serve as the evidence of the transitory nature of HPV-infection in young women (6). At the same time, 
sexual promiscuity is characteristic for adolescents, so there is a risk of their getting reinfected with the same or other types of the virus. In the recent time, cases of invasive cervical cancer in young women under 25 have been registered. A number of authors point out the upward trend in the quantity of pregnant women diagnosed with cervical pre-cancer and cancer. Throughout the world, the age of primiparas has gone up in the latest decade, due to which the average age of pregnant women also being cervical cancer patients reaches 30 years old.

Young women have a high probability of HPV infection and development of HPV-associated CIN. However, cytological findings in them are characterized by a low extent of damage, while HPV-infection is transitory (7), which underlies the selection of management tactics for young female patients (8). The contemporary treatment methods are mostly aimed at removing lesions by physical techniques; they cannot be recognized as quite satisfactory ones, and it is often the case the female patients cannot get rid of HPV with these methods (4).

\section{MATERIALS AND METHODS}

Objective of the research: optimizing the management tactics of young women having papillomavirus infection by combining interferon therapy and vaccine prevention of reinfection with tetravalent vaccine.

Tasks of the research: conducting the examination of HPVpositive young women, evaluating its results, identifying the management tactics for the HPV-positive female patients, and evaluating the efficiency of using the adopted management tactics in comparison groups at the end of the study.

Based on Moscow Regional Scientific Research Institute of Obstetrics and Gynecology, examination of 3 groups of female patients $(n=150)$ aged $16-25$ was conducted in the scientific consulting department. The period of the study was 3 years, from 2017 through 2019.

Group 1 (the retrospective observation group) consisted of women who did have human papillomavirus detected in the anamnesis but received no treatment, and follow-up examination was performed after 3 years.

Group 2 included female patients who had HPV-infection identified, and during the research in combination with antibacterial and anti-inflammatory therapy (if a concurrent urogenital infection was found), they were vaccinated with tetravalent vaccine (according to the 0-2-6 months scheme) for the purpose of preventing reinfection.

In group 3, there were women with PVI detected, who were prescribed interferon alpha-2b with antioxidants therapy (Viferon $1 \mathrm{mln}$ ME suppositories by rectal administration twice a day at the 12-hour interval, and in case of anogenital condylomata present - Viferon gel by topical application twice a day for one month) and vaccinated with tetravalent vaccine (according to the 0-2-6 months scheme).

Observation of the female patients of group 1 was started 2 years from the point of their being diagnosed with human papillomavirus, but as they got no treatment related to it, the authors considered them as the retrospective observation group.

When human papillomavirus was detected in them, group 2 women received the treatment of concurrent urogenital infection and vaginal dysbiosis as necessary. They were also vaccinated with tetravalent vaccine according to the 0-2-6 months scheme, after which the follow-up examination was conducted 2 and 3 years later. The examination included PCRdiagnostics of HPV, oncocytological study and colposcopy.

The management tactics of group 3 female patients was identical to that of group 2, however, the former additionally got a course of interferon therapy according to the above scheme. The follow-up examination was conducted 2 and 3 years later.

The IFN system is known to ensure non-specific antivirus protection of the organism. The diversity of the IFN functions gives evidence about their being elements of an intricate network of cytokines, hormones, prostaglandins and apoptosis regulators, the action of which is mutually regulated $(9,10,11)$. The integrated composition of Viferon conditions a number of effects: in combination with membrane-stabilizing agents, the antivirus activity of recombinant interferon goes up 10-14 times, its modulating action on T- and B-lymphocytes is enhanced, the content of immunoglobulin $\mathrm{E}$ is normalized, and there are no side-effects. Moreover, the Viferon gel features a pronounced local immunomodulating action. It also promotes the increase of locally formed IgA secretory class antibodies that prevent fixation and multiplication of pathogenic microorganisms on mucous membranes, which ensures the prolonged curative effect.

Vaccination with tetravalent vaccine was substantiated by the ability of immune protection against types $6,11,16$, and 18 in the female patients in the future. Meanwhile, positive experience of using the vaccine agent in HPV-positive female patients has been reflected in individual foreign studies only $(12,13)$.

\section{RESULTS AND DISCUSSION}

The average age of the examined in the groups was 18 years. All the female patients were sexually active. According to the examination results, human papillomavirus was found in all the patients (Table 1).

Anogenital condylomata were found in $22 \%$ of the female patients of group 1, in $14 \%$ of group 2 women, and in $34 \%$ of group 3 examined ones. The size of lesions ranged from 2 to 10 $\mathrm{mm}$, their quantity - from individual to multiple ones.

According to the results of cytological study of smears taken from exo- and endocervix and the PCR-diagnostics, no statistically significant distinctions between the comparison groups were found as of the beginning of the study (Table 2).

When sexually transmitted infections were found, the female patients were administered antibacterial therapy up to the clinical standards.

Taking into account the fact that group 1 women were in the retrospective observation group, they were only checked two and three years later. Female patients of groups 2 and 3 were re-examined in a month after the treatment. In them, better cytological test results were observed as well as eradication of the bacterial infection agents. Alongside this, in 10 of the patients of group $3(20 \%)$, anogenital condylomata disappeared after one month of the use of the Viferon gel. In the remaining 7 women, the size of the condylomata has decreased, and observation of them is continued. 
Table 1. Distribution of HPV in the female patients of groups 1, 2, and 3 at the beginning of the study (authors)

\begin{tabular}{|c|c|c|c|}
\hline Virus types & $\begin{array}{l}\text { group } 1 \\
\% \text { (abs.) }\end{array}$ & $\begin{array}{l}\text { group } 2 \\
\% \text { (abs.) }\end{array}$ & $\begin{array}{l}\text { group } 3 \\
\% \text { (abs.) }\end{array}$ \\
\hline HPV (overall infection) & $100(50)$ & $100(50)$ & $100(50)$ \\
\hline High cancer risk HPV & $78(39)$ & $84(42)$ & $64(32)$ \\
\hline type 16 & $70(35)$ & $64(32)$ & $58(29)$ \\
\hline type 18 & $58(29)$ & $76(38)$ & $52(26)$ \\
\hline type 6 & $34(17)$ & $20(10)$ & $50(25)$ \\
\hline type 11 & $22(11)$ & $16(8)$ & $14(7)$ \\
\hline type 31 & $20(10)$ & $16(8)$ & $26(13)$ \\
\hline type 33 & $18(9)$ & $12(6)$ & $22(11)$ \\
\hline type 58 & $14(7)$ & $10(5)$ & $22(11)$ \\
\hline type 49 & $14(7)$ & $6(3)$ & $10(5)$ \\
\hline
\end{tabular}

Table 2. Results of examination of the female patients of groups 1,2 , and 3 at the beginning of the study (authors)

\begin{tabular}{|c|c|c|c|}
\hline & $\begin{array}{l}\text { group } 1 \\
\% \text { (abs.) }\end{array}$ & $\begin{array}{l}\text { group } 2 \\
\% \text { (abs.) }\end{array}$ & $\begin{array}{l}\text { group } 3 \\
\% \text { (abs.) }\end{array}$ \\
\hline \multicolumn{4}{|c|}{ Cytological picture } \\
\hline NILM & $14(7)$ & $16(8)$ & $12(6)$ \\
\hline ASC-US & $56(28)$ & $62(31)$ & $66(33)$ \\
\hline LSIL & $24(12)$ & $18(9)$ & $16(8)$ \\
\hline $\mathrm{HSIL}$ & $6(3)$ & $4(2)$ & $6(3)$ \\
\hline \multicolumn{4}{|c|}{ Colposcopic picture } \\
\hline Abnormal colposcopic picture & $62(31)$ & $54(27)$ & $58(29)$ \\
\hline STD & $42(21)$ & $64(32)$ & $52(26)$ \\
\hline Chlamydia trachomatis & $10(5)$ & $8(4)$ & $12(6)$ \\
\hline Mycoplasma hominis & $26(13)$ & $22(11)$ & $30(15)$ \\
\hline Mycoplasma genitalium & $18(9)$ & $14(7)$ & $10(5)$ \\
\hline $\begin{array}{l}\text { Ureaplasma urealyticum/ } \\
\text { Ureaplasma parvum }\end{array}$ & $32(16)$ & $28(14)$ & $22(11)$ \\
\hline Herpes simplex virus & $14(7)$ & $8(4)$ & $16(8)$ \\
\hline Trichomonas vaginalis & $2(1)$ & - & $4(2)$ \\
\hline
\end{tabular}

Table 3. Distribution of HPV in the female patients of groups 1, 2, and 3 over time (authors)

\begin{tabular}{|c|c|c|c|c|c|c|c|c|c|}
\hline & \multicolumn{3}{|c|}{ group $1(n=50)$} & \multicolumn{3}{|c|}{ group $2(n=50)$} & \multicolumn{3}{|c|}{ group $3(n=50)$} \\
\hline & $\begin{array}{c}\text { At the } \\
\text { beginning } \\
\text { of the study }\end{array}$ & $\begin{array}{l}2 \text { years } \\
\text { later }\end{array}$ & $\begin{array}{c}3 \text { years } \\
\text { later }\end{array}$ & $\begin{array}{c}\text { At the } \\
\text { beginning } \\
\text { of the study }\end{array}$ & $\begin{array}{c}2 \text { years } \\
\text { later }\end{array}$ & $\begin{array}{l}3 \text { years } \\
\text { later }\end{array}$ & $\begin{array}{c}\text { At the } \\
\text { beginning } \\
\text { of the study }\end{array}$ & $\begin{array}{c}2 \text { years } \\
\text { later }\end{array}$ & $\begin{array}{l}3 \text { years } \\
\text { later }\end{array}$ \\
\hline & $\%$ (abs.) & $\%$ (abs.) & $\%$ (abs.) & $\%$ (abs.) & $\%$ (abs.) & $\%$ (abs.) & $\%$ (abs.) & $\%$ (abs.) & $\%$ (abs.) \\
\hline $\begin{array}{c}\text { HPV } \\
\text { (overall infection) } \\
\end{array}$ & $100(50)$ & $72(36)$ & $70(35)$ & $100(50)$ & $46(23)$ & $40(20)$ & $100(50)$ & $30(15)$ & $8(4)$ \\
\hline High-risk HPV & $78(39)$ & $62(31)$ & $66(33)$ & $84(42)$ & $44(22)$ & $38(19)$ & $64(32)$ & $26(13)$ & $8(4)$ \\
\hline type 16 & $70(35)$ & $62(31)$ & $58(29)$ & $64(32)$ & $26(13)$ & $24(12)$ & $58(29)$ & $16(8)$ & $4(2)$ \\
\hline type 18 & $58(29)$ & $28(14)$ & $26(13)$ & $76(38)$ & $42(21)$ & $38(19)$ & $52(26)$ & $20(10)$ & $2(1)$ \\
\hline type 6 & $34(17)$ & $34(17)$ & $30(15)$ & $20(10)$ & $14(7)$ & $6(3)$ & $50(25)$ & - & - \\
\hline type 11 & $22(11)$ & - & $18(9)$ & $16(8)$ & $10(5)$ & $8(4)$ & $14(7)$ & $4(2)$ & - \\
\hline type 31 & $20(10)$ & $20(10)$ & $18(9)$ & $16(8)$ & $12(6)$ & $8(4)$ & $26(13)$ & - & - \\
\hline type 33 & $18(9)$ & - & $14(7)$ & $12(6)$ & $12(5)$ & $6(3)$ & $22(11)$ & - & - \\
\hline type 58 & $14(7)$ & $14(7)$ & $14(7)$ & $10(5)$ & - & - & $22(11)$ & $2(1)$ & $2(1)$ \\
\hline type 49 & $14(7)$ & $14(7)$ & $12(6)$ & $6(3)$ & - & - & $10(5)$ & - & - \\
\hline Other types of HPV & - & $24(12)$ & $34(17)$ & - & - & - & - & - & - \\
\hline
\end{tabular}

It should be pointed out that so early as in two years from the beginning of the research, the highest frequency of elimination of human papillomavirus occurred in the female patients of group 3, with a similar trend noted at the end of the research, too. New types of the virus, the presence of multiple HPV types in most patients, and the highest persistence of the virus were found in group 2 of the female patients who had not received vaccination and interferon therapy. More active elimination has been registered in the carriers of lowoncogenic types, which is the case in all the groups under study. This is in line with the world data about more frequent elimination of the low cancer risk viruses. At the same time, three years later, it is in the female patients of group 1 that some HPV types were detected again after elimination (Table 3).

In two years, anogenital condylomata were found in 13 female patients of group 1 (26\%), 6 female patients of group 2 $(12 \%)$, while they were not found in any of group 3 women. For the patients of groups 1 and 2, destructive condyloma removal methods were used.

At the end of observation, in group 3, no STDs were found in any of the female patients, as compared to those of groups 1 and 2, which confirms the positive effect of interferon therapy combined with antibacterial therapy on the immune status.

Cytological check findings have shown that group 1 women had no statistically significant improvement. As for the 
Table 4. Results of examination of the female patients of groups 1, 2, and 3 at the end of the study (authors)

\begin{tabular}{|c|c|c|c|c|c|c|c|c|c|}
\hline & \multicolumn{3}{|c|}{ group $1(n=50)$} & \multicolumn{3}{|c|}{ group $2(n=50)$} & \multicolumn{3}{|c|}{ group $3(n=50)$} \\
\hline & $\begin{array}{c}\text { At the } \\
\text { beginning of } \\
\text { the study }\end{array}$ & 2 years later & 3 years later & $\begin{array}{c}\text { At the } \\
\text { beginning of } \\
\text { the study }\end{array}$ & 2 years later & 3 years later & $\begin{array}{c}\text { At the } \\
\text { beginning of } \\
\text { the study }\end{array}$ & 2 years later & 3 years later \\
\hline & $\%$ (abs.) & $\%$ (abs.) & $\%$ (abs.) & $\%$ (abs.) & $\%$ (abs.) & $\%$ (abs.) & $\%$ (abs.) & $\%$ (abs.) & $\%$ (abs.) \\
\hline NILM & $14(7)$ & $10(5)$ & $18(9)$ & $16(8)$ & $60(30)$ & $84(42)$ & $12(6)$ & $92(46)$ & $96(48)$ \\
\hline ASC-US & $56(28)$ & $58(29)$ & $68(34)$ & $62(31)$ & $38(19)$ & $14(7)$ & $66(33)$ & $8(4)$ & $4(2)$ \\
\hline LSIL & $24(12)$ & $22(11)$ & $6(3)$ & $18(9)$ & $2(1)$ & - & $16(8)$ & - & - \\
\hline HSIL & $6(3)$ & $10(5)$ & $8(4)$ & $4(2)$ & - & $2(1)$ & $6(3)$ & - & - \\
\hline
\end{tabular}

Table 5. Comparative data of examination of the female patients at the beginning and at the end of the study (authors)

\begin{tabular}{|c|c|c|c|c|c|c|c|c|c|}
\hline & \multicolumn{3}{|c|}{ group $1(n=50)$} & \multicolumn{3}{|c|}{ group $2(n=50)$} & \multicolumn{3}{|c|}{ group $3(n=50)$} \\
\hline & $\begin{array}{c}\text { At the } \\
\text { beginning } \\
\text { of the study }\end{array}$ & $\begin{array}{l}2 \text { years } \\
\text { later }\end{array}$ & $\begin{array}{l}3 \text { years } \\
\text { later }\end{array}$ & $\begin{array}{c}\text { At the } \\
\text { beginning } \\
\text { of the study }\end{array}$ & $\begin{array}{l}2 \text { years } \\
\text { later }\end{array}$ & $\begin{array}{l}3 \text { years } \\
\text { later }\end{array}$ & $\begin{array}{c}\text { At the } \\
\text { beginning } \\
\text { of the study }\end{array}$ & $\begin{array}{l}2 \text { years } \\
\text { later }\end{array}$ & $\begin{array}{l}3 \text { years } \\
\text { later }\end{array}$ \\
\hline & $\%$ (abs.) & $\%$ (abs.) & $\%$ (abs.) & $\%$ (abs.) & $\%$ (abs.) & $\%$ (abs.) & $\%$ (abs.) & $\%$ (abs.) & $\%$ (abs.) \\
\hline $\begin{array}{c}\text { HPV } \\
\text { (overall infection) }\end{array}$ & $100(50)$ & $72(36)$ & $70(35)$ & $100(50)$ & $46(23)$ & $40(20)$ & $100(50)$ & $30(15)$ & $8(4)$ \\
\hline High-risk HPV & $78(39)$ & $62(31)$ & $66(33)$ & $84(42)$ & $44(22)$ & $38(19)$ & $64(32)$ & $26(13)$ & $8(4)$ \\
\hline 16 type & $70(35)$ & $62(31)$ & $58(29)$ & $64(32)$ & $26(13)$ & $24(12)$ & $58(29)$ & $16(8)$ & $4(2)$ \\
\hline 18 type & $58(29)$ & $28(14)$ & $26(13)$ & $76(38)$ & $42(21)$ & $38(19)$ & $52(26)$ & $20(10)$ & $2(1)$ \\
\hline 6 type & $34(17)$ & $34(17)$ & $30(15)$ & $20(10)$ & $14(7)$ & $6(3)$ & $50(25)$ & - & - \\
\hline 11 type & $22(11)$ & - & $18(9)$ & $16(8)$ & $10(5)$ & $8(4)$ & $14(7)$ & $4(2)$ & - \\
\hline 31 type & $20(10)$ & $20(10)$ & $18(9)$ & $16(8)$ & $12(6)$ & $8(4)$ & $26(13)$ & - & - \\
\hline 33 type & $18(9)$ & - & $14(7)$ & $12(6)$ & $12(5)$ & $6(3)$ & $22(11)$ & - & - \\
\hline 58 type & $14(7)$ & $14(7)$ & $14(7)$ & $10(5)$ & - & - & $22(11)$ & $2(1)$ & $2(1)$ \\
\hline 49 type & $14(7)$ & $14(7)$ & $12(6)$ & $6(3)$ & - & - & $10(5)$ & - & - \\
\hline Other types of HPV & - & $24(12)$ & $34(17)$ & - & - & - & - & - & - \\
\hline \multicolumn{10}{|c|}{ Cytological picture } \\
\hline NILM & $14(7)$ & $10(5)$ & $18(9)$ & $16(8)$ & $60(30)$ & $84(42)$ & $12(6)$ & $92(46)$ & $96(48)$ \\
\hline ASC-US & $56(28)$ & $58(29)$ & $68(34)$ & $62(31)$ & $38(19)$ & $14(7)$ & $66(33)$ & $8(4)$ & $4(2)$ \\
\hline LSIL & $24(12)$ & $22(11)$ & $6(3)$ & $18(9)$ & $2(1)$ & - & $16(8)$ & - & - \\
\hline HSIL & $6(3)$ & $10(5)$ & $8(4)$ & $4(2)$ & - & $2(1)$ & $6(3)$ & - & - \\
\hline
\end{tabular}

repeated detection of HSIL (CINII), this required performing colposcopy-guided biopsy of the cervix and using destructive treatment methods. In groups 2 and 3, the cytological test results have shown reduced frequency of signs of cervicitis as well as those of cervical neoplasia so early as in two years. At the end of the research, in the female patients of group 3, stabilization of the normal cytological picture was noted, as compared to group 2 women (Table 4).

At the end of the study, anogenital condylomata were found in 10 and 5 female patients of groups 1 and 2, respectively $(10 \%$ and $5 \%)$. Meanwhile, recurrence of the condylomata was registered in 7 women of group 1.

Summing up the research findings, it should be noted once again that in the groups under comparison, it is in the female patients of group $3(56 \%)$ that the highest frequency of elimination of high-risk HPV took place, as compared to those of groups 1 and 2 ( 12 and 46\%, respectively). The highest extent of persistence of all types of the virus was registered in group 1 women $(70 \%)$, while it was minimum in the women of group 3 , making $8 \%$; in group 2 patients, persistence of the virus of all types amounted to $20 \%$. During observation, new types of HPV were only found in group 1 women. The best result concerning anogenital condylomata was obtained in the female patients of group 3, too, and the highest frequency of relapses - in group 2. The increase of the occurrence of HPV-associated cervicitis and progression of cervical neoplasia were also found to a greater extent in the women of group 1, unlike group 2 female patients, while in group 3, regression of precancerous lesions was registered (Table 5).

\section{CONCLUSION}

The World Health Organization emphasizes the severity of the problem of diseases caused by HPV for the international public healthcare and recommends including HPV-vaccines into the national immunization programs. Women should be reminded that vaccination does not cancel the necessity of having routine gynecological examinations for the purposes of secondary prevention. The algorithm of performing preventive examinations has to be developed, too, including the means for notifying the entire female population of the regulated age, convenient logistics, receiving and interpreting the test results.

The conducted observation of HPV-infection course has shown that the management tactics adopted for female patients having latent and subclinical forms of the infection which included the use of the interferon alpha immunomodulating agent as well as prevention with tetravalent vaccine in the observation group gives a more pronounced positive effect as compared to the comparison groups. The combined positive effect is based on the fact that vaccination with tetravalent vaccine protects the female patients against being infected and recontaminated by viruses of types $6,11,16$, and 18 , while interferon therapy helps boost the immune system for fighting the existing viruses. The adopted management tactics of HPV-positive young women including vaccination and the use of interferon has allowed obtaining better results in elimination of the virus, reduction of the frequency of cervical neoplasia and HPV-associated 
cervicitis in the female patients. It also prevents reinfection with the virus and the recurrence of anogenital condylomata.

Thus, alongside with screening programs, preventive vaccination against $\mathrm{HPV}$ is a part of coordinated strategy and tactics of countering the CC and other HPV-associated diseases, and the integrated approach to HPV-positive female patients using vaccination and interferon therapy contributes to elimination of HPV and reduces the frequency of relapses of the infection considerably. Moreover, in female patients having latent and subclinical forms of PVI, such management tactics allows taking measures to prevent malignization of the process and reducing the risk of complications, which has a positive impact on the reproductive potential of young women.

\section{REFERENCES}

1. Rogovskaya SI. Papillomavirus infection in women and cervical pathology. Moscow: GEOTAR-Media; 2014.

2. Baranov AA, Namazova-Baranova LS, Tatochenko VK, Vishnyova EA, Fedoseenko MV, Selimzyanova LR, et al. Vaccine prevention of diseases caused by the human papillomavirus: standpoints of evidence-based medicine. Review of clinical guidelines. Current Pediatrics. 2017;16(2):107-17. https://doi.org/10.15690/vsp.v16i2. 1711

3. Zarochentseva NV, Belaiya JM. Papillomavirus infection in adolescent girls: particularities of the course and management tactics. Gynecology, Obstetrics, and Perinatology. 2018;17(5): 21-8. https://doi.org/10.20953/ 1726-1678-2018-5-21-28

4. Tainio K, Athanasiou A, Tikkinen KAO, Aaltonen R, Cárdenas $\mathrm{J}$, Hernándes. Clinical course of untreated cervical intraepithelial neoplasia grade 2 under active surveillance: systematic review and meta-analysis. BMJ. 2018; 360:k499. https://doi.org/10.1136/bmj.k499 PMid:29487049 PMCid: PMC5826010

5. Papillomavirus infection: main lines in diagnosing and treatment. Gynecology. 2017;19(6):34-7. https://doi.org/ 10.26442/2079-5696_19.6.34-37
6. Loopik DL, Bekkers RLM, Massuger LFAG, Melchers WJG, Siebers AG, Bentley J. Justifying conservative management of CIN2 in women younger than 25 years - A populationbased study. Gynecologic Oncology. 2019;152(1):82-6. https://doi.org/10.1016/j.ygyno.2018.10.038 PMid:30413339

7. Paul L. Drugs Tetravalent recombinant vaccine against human papillomavirus (types $6,11,16,18$ ) (Gardasil): an analysis of the use for the prevention of precancerous rectal lesions, cervical cancer, cancer of the anal canal and genital warts. 2014;74:1253-83. https://doi.org/10.2165/ 11204920-000000000-00000 PMid:21142263

8. Adamyan LV, Artymuk NV, Ashrafyan LA, et al. Benign and precancerous diseases of the cervix from the standpoint of cancer prevention. Clinical guidelines (diagnosing and patient management protocols). 2017;55:117-207. Available at: https://kraszdrav.ru/assets/documents/ Protokol_po_sheyke_matke_MZ_RF_ot_02.11.201707.11. 2017\%2014:05.pdf

9. Bitsadze VO, Khamani NM, Makatsariya NA. The place of immunomodulating agents in controlling the HPVassociated diseases: problems and prospects. Obstetrics, Gynecology, and Reproduction. 2016;3:76-84. https://doi.org/10.17749/2313-7347.2016.10.2.076-084

10. Klimova RR, Malinovskaya VV, Parshina OV, Guseva TS, Novikova SV, Torshina ZV, et al. The impact of viral infections on the cytokine profile in pregnant women having an aggravated obstetric anamnesis and immune correction therapy with human interferon alpha- $2 b$. Problems of Virology. 2013;58(1):18-23.

11. Roik EE, Baranov AN, Treshcheva ND. Epidemiological particularities of papillomavirus infection. Human Ecology. 2015;5:21-6. https://doi.org/10.33396/1728-0869-2015-521-26

12. Radzinskiy VE, Ordiyants IM, Bebneva TN. Fighting HPV: many facets of the single problem. Integrated therapy of HPV-associated diseases: newsletter. Moscow: Editorial board of the StatusPraesens journal; 2018.

13. Leval A, Herweijer E, Ploner A. Quadrivalent human papillomavirus vaccine effectiveness: a Swedish national cohort study. Journal of the National Cancer Institute. 2013;105(7):469-74. https://doi.org/10.1093/jnci/djt032 PMid:23486550 PMCid:PMC3614506 